\title{
Logistics of Entry and Parking of Vehicles at Large Production Companies
}

\author{
Jozef Gnap ${ }^{1, *}$, Pavol Varjan ${ }^{1}$, and Štefánia Semanová ${ }^{1}$ \\ ${ }^{1}$ University of Žilina, Faculty of Operation and Economics of Transport and Communications, \\ Department of Road and Urban Transport, Univerzitná 8215/1, 01026 Žilina, Slovakia
}

\begin{abstract}
The paper deals with the logistics of entry of freight vehicles to be unloaded or loaded in logistics and industrial parks. This problem is not systematically addressed when designing new logistics parks and industrial companies in the Slovak Republic neither in Europe nor in the world. Based on the research applied to the production company, a methodology for calculating the number of parking spaces was proposed. As it is possible to use simulation methods for solving this issue, the authors also deal with this possibility. The aim is to verify the accuracy of the proposed coefficients as well as to propose changes in the Slovak technical standard.
\end{abstract}

\section{Introduction}

The logistics of entry of freight vehicles to be unloaded or loaded within logistics and industrial parks is an issue which must be addressed systematically already when designing new logistics or industrial parks. Unfortunately, many newly built industrial companies as well as logistics parks in the Slovak Republic do not have any parking lots for freight vehicles in front of entries to their premises. However, these companies often require adherence to loading and unloading time windows (e.g. two hours), even in the case of long distance transport of over $1000 \mathrm{~km}$. Furthermore, the companies assume that carriers plan the transport in compliance with compulsory safety breaks, daily and weekly rest periods with the use of public parking lots or carriers try to avoid complying with the social legislation (e.g. using magnets to disable tachographs).

The capacity of public parking lots for road freight vehicles is insufficient in Europe $[1,2]$. Also, some cities restrict parking or entry of freight vehicles into wider city centres.

By using specific cases, the authors of the paper point out that it is necessary to deal with the logistics of entry of freight vehicles into logistics and industrial areas, also with regard to introducing intelligent tachographs which will be connected to GNSS and thus breaking the social legislation will not be possible. Therefore, logistics managers in logistics parks and industrial companies should have an overview of the requirements of Regulation (EC) No. 561/2006 on the harmonisation of certain social legislation relating to road transport and they should plan schedules for transport including loading and unloading in respect of this regulation [3]. The designers of logistics and industrial parks should have data on the number of parking spaces to be designed for freight vehicles. Based on own

*Corresponding author: jozef.gnap@fpedas.uniza.sk 
research, the authors proposed a procedure for calculating the necessary number of parking spaces for articulated freight vehicles.

\section{Problems of the logistics of entry and parking of vehicles at large production companies}

\subsection{Approach to the problem solving for the production company}

Department of Road and Urban Transport elaborated an expert study for the large company MONDI SCP, a.s. The expert study dealt with the issue of entry of freight vehicles into the company premises and its main objective was to shorten the waiting time before entering the company and time of staying inside the company [4].

The first step of this study was to identify the flows of incoming and outgoing vehicles. It was necessary to carry out a survey in order to verify the data provided by the company. The survey objective was to obtain input data for a deeper analysis of times of freight vehicle movements, duration of individual activities related to loading as well as workload of the gatehouse at the entrance to the company.

During the survey, the following time intervals were measured:

- Vehicle turnover - time interval between stopping a vehicle onto the scale when entering the company and its departure from the scale when leaving the company.

- Time spent in warehouses - time interval between the vehicle arrival at the parking lot before loading and its departure from the parking lot after completed loading (this applies to those vehicles which are loaded only in one warehouse). In the case that a vehicle is loaded in several warehouses, this indicator represents a time interval between the arrival at the parking lot of the first warehouse and departure from the parking lot of the last warehouse.

- Vehicle turnover in the warehouse - time interval between the vehicle arrival at the parking lot of the particular warehouse before loading and its departure after completed loading.

- Waiting time before loading - time measured from the moment when the vehicle arrives at the parking lot till it is moved to the loading ramp and ready to be loaded.

- Loading time - time between arrival at/departure from the loading ramp.

- Waiting time after loading - time interval between leaving the loading ramp and departure from the parking lot after document processing.

Based on the data obtained from the survey, the following indicators were evaluated:

- vehicle turnover,

- overall time that the vehicle spends in warehouses,

- time that vehicle spends in individual warehouses as well as duration of individual activities performed in those warehouses (waiting time before loading, loading time, document processing after loading),

- load of the entry road by incoming and outgoing freight vehicles.

As an example, Figure 1 depicts the processed results of the survey that was carried out between 5:38 and 11:40.

The turnover of all vehicles arriving for loading and unloading was measured. In overall, 51 vehicles were observed to enter and also leave the company. Within the observed vehicles, the minimum time of turnover represented 39 minutes and the maximum turnover time was 4 hours and 9 minutes. The average turnover time was 2 hours and 5 minutes. Figure 2 depicts the measured turnover times of individual vehicles. 


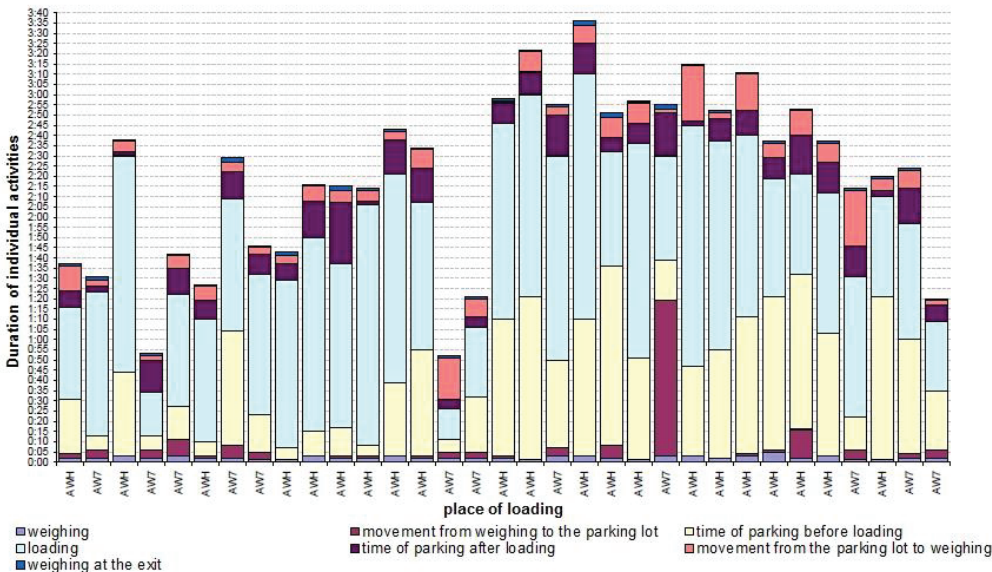

Fig. 1. The measured duration of individual activities of vehicles during their stay in the company. Source: [4]

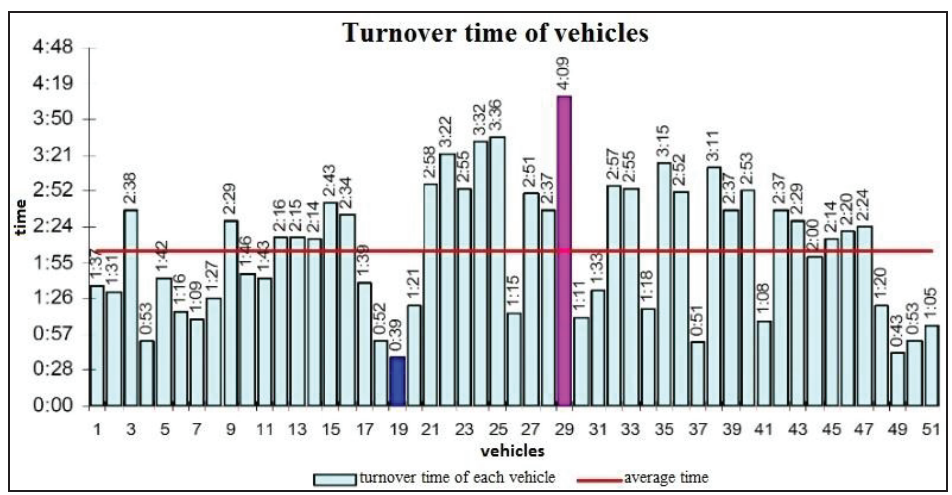

Fig. 2. Turnover time of vehicles. Source: [4]

If large companies do not address the logistics of entry and parking of freight vehicles incoming into the company, problems with traffic congestion or violation of the social legislation mainly in terms of adherence to daily and weekly rest periods may occur. The problems with violation of the social legislation arise mostly as a result of waiting time before loading, blocking public roads and staying in the company premises. The output from the expert study was a proposal to change the organization of entry and parking in front of the company. Other proposals included placing the second scale for weighing vehicles at the exit and changing the system of vehicle routing inside the company campus. One of the proposals was successfully implemented and it contributed to improving the logistics of entry of freight vehicles into the company.

\subsection{Calculation of the necessary number of parking spaces at logistics and industrial parks}

At present, a 24-hour operation is very common in large production companies. Therefore, high intensity of freight transport can be assumed for such companies. These companies often require carriers to adhere to loading and unloading time windows (e.g. two hours). The issue of parking of freight vehicles is, of course, related to this fact. If a company does not ensure a sufficient number of parking spaces already within constructing new 
production buildings or does not build additional parking capacity when needed, the following complications may arise:

- crowded parking areas around public roads near the companies; this may result in "dangerous parking" in some cases,

- driving even during compulsory breaks and rest periods may have negative impact on the safety of other road users,

- inadequate or no services provided to drivers at parking areas or pollution of the road infrastructure surroundings.

\subsubsection{The issue of freight vehicle parking at KIA Motors Slovakia}

KIA Motors Slovakia launched its production in 2006. In 2016, the company produced more than 339500 cars and 612000 engines [5].

The company campus can be used as a good example for solving the problem of the logistics of entry and parking of freight vehicles. This production company has a parking lot which is, however, designed only for passenger cars and buses. There is no parking lot determined for freight vehicles. As already mentioned in the paper, production companies often require adherence to loading and unloading time windows. However, some companies do not allow to park freight vehicles inside its premises mainly due to limited space. As KIA Motors Slovakia does not have a parking lot for freight vehicles, problems with parking arise.

The second problem related to freight transport is adherence to the requirements of Regulation (EC) No. 561/2006 on the harmonisation of certain social legislation relating to road transport. Examination within the expert study mentioned in Chapter 2.1 showed that the average time of a vehicle turnover was 2 hours and 9 minutes with the assigned time window (e.g. 2 hours). Oftentimes, drivers must take compulsory breaks, daily or weekly rest periods after unloading (or loading). As they do not have possibility to stop and park their vehicle within the company campus, they have to look for a solution not to break the social legislation. One of possibilities is to apply the exception set out in Chapter IV, Article 12 of Regulation (EC) No. 561/2006: "Provided that road safety is not thereby jeopardised and to enable the vehicle to reach a suitable stopping place, the driver may depart from Articles 6 to 9 to the extent necessary to ensure the safety of persons, of the vehicle or its load. The driver shall indicate the reason for such departure manually on the record sheet of the recording equipment or on a printout from the recording equipment or in the duty roster, at the latest on arrival at the suitable stopping place" [6]. The driver can manually indicates the exception and reason on the record sheet or the printout from the recording device; however, additional driving time may take only a few minutes unless the driver finds a safe place to stop. Such a place should be a proper parking lot designed for freight vehicles and not the edge of public roads.

In case of KIA Motors Slovakia, the problem is the absence of a freight vehicle parking lot that is designed only for this company. For example, such parking lots can be seen in the car factory PSA Trnava in the Slovak Republic. It is also necessary to note that there is insufficient number of public parking lots near KIA e.g. at petrol stations. The nearest petrol station, which is about $2.5 \mathrm{~km}$ away from KIA depending on the entrance to the company, has available only 12 parking spaces for freight vehicles. This petrol station is very often used by carriers serving KIA production company. Moreover, nearby the city of Žilina, there is no rest area planned yet that could be used for temporary parking of freight vehicles before arriving at the company for loading or unloading in accordance with the time windows. Therefore, freight vehicles park on public roads near the company premises (Fig. 3). 


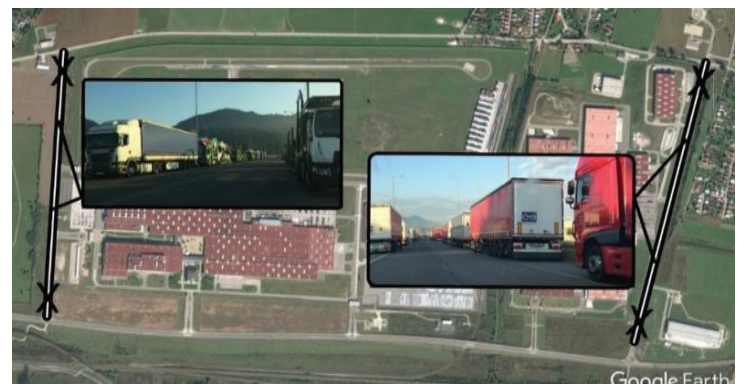

Fig. 3. Parking of freight vehicles near KIA. Source: authors, based on Google maps

\subsubsection{Calculation of the number of parking spaces at KIA Motors Slovakia}

In terms of the theoretical calculation of the number of parking spaces intended for freight transport, it was first necessary to obtain data on the number of freight vehicles incoming into the company. The survey was carried out on $20^{\text {th }}$ and $21^{\text {st }}$ October 2016 (Thursday and Friday) at predetermined locations near individual entrances to the company (three entrances intended for freight transport). A 24-hour survey was employed to obtain the most accurate information about the number of freight vehicles of $\mathrm{N} 3$ category. As the time window before entering the company was set at the level of 2 hours, it was necessary to divide the transport intensity into 2-hour intervals. Tab. 1 contains two-hour intensity intervals of freight vehicles of $\mathrm{N} 3$ category incoming into the company campus. Data are provided separately for each entrance as well as in overall. For the theoretical number of parking spaces calculated for whole production company, however, it is sufficient to work further only with the total number of observed incoming vehicles.

Table 1. Intensity of entry of N3 category freight vehicles. Source: authors

\begin{tabular}{|c|c|c|c|c|c|c|c|c|c|c|c|c|}
\hline & $\begin{array}{l}12: 00- \\
14: 00\end{array}$ & $\begin{array}{l}14: 00- \\
16: 00\end{array}$ & $\begin{array}{l}16: 00- \\
18: 00\end{array}$ & $\begin{array}{l}18: 00- \\
20: 00\end{array}$ & $\begin{array}{l}20: 00- \\
22: 00\end{array}$ & $\begin{array}{l}22: 00- \\
24: 00\end{array}$ & $\begin{array}{l}\text { 00:00- } \\
02: 00\end{array}$ & $\begin{array}{l}02: 00- \\
04: 00\end{array}$ & $\begin{array}{c}\text { 04:00- } \\
06: 00\end{array}$ & $\begin{array}{c}\text { 06:00- } \\
08: 00\end{array}$ & $\begin{array}{l}\text { 08:00- } \\
10: 00\end{array}$ & $\begin{array}{l}10: 00- \\
12: 00\end{array}$ \\
\hline $\begin{array}{c}\text { Entrance } \\
1\end{array}$ & 14 & 23 & 26 & 10 & 11 & 11 & 15 & 10 & 14 & 22 & 16 & 9 \\
\hline $\begin{array}{c}\text { Entrance } \\
2\end{array}$ & 32 & 36 & 24 & 26 & 32 & 24 & 23 & 19 & 18 & 39 & 36 & 51 \\
\hline $\begin{array}{c}\text { Entrance } \\
3\end{array}$ & 12 & 14 & 5 & 5 & 12 & 6 & 7 & 14 & 10 & 7 & 16 & 16 \\
\hline Total & 58 & 73 & 55 & 41 & 55 & 41 & 45 & 43 & 42 & 68 & 68 & 76 \\
\hline
\end{tabular}

Based on Tab. 1, it can be concluded that the highest intensity of freight transport was between 10:00 and 12:00 h. During this time interval, 76 freight vehicles of N3 category entered into the company. This means that 76 freight vehicles would have to wait 2 hours before entering the company and therefore at least 76 parking spaces would be needed. This value is then the basis for next calculation. However, this value should be increased by a share of vehicles which must draw daily or weekly rest period before loading or unloading. The calculation of the number of parking spaces for the vehicles drawing a daily or weekly rest period was based on the total number of vehicles entering the company. During the survey, 655 freight vehicles entered and 645 vehicles exited the company campus. The following formula was used for the calculation:

$$
P P M=I_{\max }+\left(P V_{D O} \div k_{p d}\right)+\left(P V_{T O} \cdot k_{p t}\right)
$$

Where: $P P M$ - necessary number of parking spaces; $I_{\max }$ - maximum intensity of entry of vehicles in 2-hour intervals [vehicles]; $P V_{D O}$ - number of vehicles, drivers of which draw a daily rest period [vehicles]; $k_{p d}$ - coefficient of the use of a parking space by vehicles, the 
drivers of which take daily rest periods; $k_{p t}$ - coefficient of the use of a parking space by vehicles, the drivers of which take weekly rest periods, $P V_{T O}$ - number of vehicles, drivers of which draw a weekly rest period [vehicles].

Further, it was necessary to determine a share of those freight vehicles, drivers of which draw daily and weekly rest periods before/after loading or unloading. To determine this share, further surveys were carried out to find out the number of vehicles parked at observed locations for at least 11 hours (daily rest period) and 45 hours (regular weekly rest period). The number of freight vehicles parked at the petrol station near the company (mentioned in Chapter 2.2.1) and on the road sections (marked with black and white lines in Fig. 3) was surveyed. A part of the first survey was carried out on $14^{\text {th }}$ August 2017 (Monday) at 19:00. The vehicle registration numbers (VRN) of N3 category vehicles parked at observed locations were recorded. The second part of the survey was then carried out on $15^{\text {th }}$ August 2017 (Tuesday) at 6:00 in the morning and vehicle registration numbers were again recorded and matched with those from the previous evening. The same procedure of the survey was repeated on $16^{\text {th }}$ and $17^{\text {th }}$ August 2017 (Wednesday and Thursday). The results are processed in Tab. 2.

The second survey was focused on determination of the number of vehicles parked due to drawing a regular weekly rest period (at least $45 \mathrm{~h}$ ). The procedure was the same as in the previous survey (dealing with the share of vehicles drawing a daily rest period). The survey started on $19^{\text {th }}$ August 2017 (Saturday) at 7:00 and it lasted till 8:30. The next observation was then carried out on $21^{\text {st }}$ August 2017 (Monday) at 6:30. The results are shown in Tab. 2.

Table 2. The average number of parked vehicles (daily/regular weekly rest period). Source: authors

\begin{tabular}{|c|c|c|c|c|}
\hline Daily & Evening (19:00_19:30) & Morning (6:00_6:30) & Match & Share [\%]* \\
\hline No. of vehicle & 34 & 45 & 22 & $3.23 \%$ \\
\hline Weekly & Saturday (07:00_8:30) & Monday (6:30_7:15) & Match & Share [\%]* \\
\hline No. of vehicle & 33 & 39 & 23 & $3.46 \%$ \\
\hline
\end{tabular} * calculated from the total number of incoming vehicles during the survey mentioned in Chapter $2.2 .2(665$
vehicles =100\%)

When calculating the number of parking spaces for vehicles, the drivers of which draw a daily rest period, it is necessary to take into account duration of the regular rest period which is 11 hours. Therefore, the survey result of 22 vehicles, which on average draw the daily rest period, is to be further divided by the coefficient $-k_{p d}$. This coefficient expresses how many times one parking space can be used by alternating vehicles, the drivers of which draw the daily rest period. Taking into account the daily rest period of 11 hours, the coefficient can be calculated as:

$$
k_{p d}=24 \text { hours } \div 11 \text { hours }=2.182
$$

To calculate the number of parking spaces for vehicles, the drivers of which draw a weekly rest period, the results of the survey focused on the rest period lasting at least 45 hours are used. The result represented 23 vehicles. As the calculation is based on the 24-hour survey and the regular weekly rest period is at least 45 hours, the value of 23 vehicles is to be multiplied by the coefficient $-k_{p t}$. This coefficient takes into account that a vehicle drawing the 45 -hour weekly rest period is, of course, parked longer than 24 hours.

$$
k_{p t}=45 \text { hours } \div 24 \text { hours }=1.875
$$

The calculated values can be then fitted into the formula (1):

$$
\begin{gathered}
P P M=76+(22 \div 2.182)+(23 \cdot 1.875) \\
P P M=76 \text { veh }+10.083 \text { veh. }+43.125 \text { veh. } \\
P P M=129.208 \text { vehicles }
\end{gathered}
$$


Under the given conditions and regarding the intensity of entry of N3 category freight vehicles, it is can be concluded that there is a need to ensure 130 parking spaces.

\subsubsection{Proposal for a calculation of parking spaces at logistics and industrial parks}

In Chapter 2.2.2, we calculated the number of parking spaces at the production company of KIA Motors Slovakia on the basis of data obtained from the surveys conducted. The following formula (1) can be used as a basis to propose general procedure for the calculation which can be used when constructing new logistics and industrial parks.

$$
P P M=I_{\max }+\left(P V_{D O} \div k_{p d}\right)+\left(P V T O . k_{p t}\right)
$$

Where: $k_{p d}=2.182$ and $k_{p t}=1.875$

To refine the formula (coefficient adjustment), it would be appropriate to carry out more surveys. This calculation proposal addresses only the issue of number of parking spaces; however, it is necessary to note that parking lots should be also equipped with social facilities (toilets, showers or refreshments).

\subsection{Possibilities of using simulation methods to refine the calculation of the number of parking spaces}

Based on examining open and closed queueing theory systems applied for simulating operation time of freight vehicles in practice, the Erlang distribution seems to be the most appropriate to be employed [7]. As mentioned in [8] and [9], the case of so-called shifted probability distribution is very common in transport technology.

The distribution function of a random variable is:

$$
F(y)=\int_{y_{0}}^{y} \frac{b^{a} \cdot\left(y-y_{0}\right)^{a-1}}{\Gamma(a)} e^{\left[-b\left(y-y_{0}\right)\right] d y}
$$

If parameter $a$ is an integer, this indicates that a random variable has the shifted Erlang distribution with the following distribution function:

$$
F e(y)=1-e^{-b\left(y-y_{0}\right)} \cdot \sum_{j=1}^{a-1} \frac{\left[b \cdot\left(y-y_{0}\right)\right]^{j}}{j !}
$$

Parameter $y_{0}$ (shifting) is calculated in practice as a minimum technological time necessary for loading or unloading of a freight vehicle with certain cargo.

In simulation models, we can use the theoretical probability distribution to obtain random variables if we acquire the input data of an appropriate range and quality and the goodness of fit test (Chi-squared test, Kolmogorov-Smirnov test) does not show deviations at the selected significance level. In this particular case, the shifted Erlang distribution seems to be the most appropriate to be used.

Based on the above mentioned characteristics, the flowchart of the simulation model for open and closed queueing theory system for operation of dumpers was created [7]. After adjustment, this model can be also used when examining the logistics of entry of freight vehicles into logistics and industrial parks as well as intermodal transport terminals [10].

\section{Conclusion}

The objective of the paper was to point out the selected aspects of the issue of logistics of entry and parking at large logistics and industrial parks. The authors provided the outputs of the research which dealt with the issue of entry of freight vehicles into the particular company campus. The main goal of the survey was to shorten waiting time before entering the company as well as time of staying inside the company premises. The paper also 
pointed out the problems associated with no or insufficient capacity of parking spaces. This problem is also related to the social legislation of drivers' work time.

As in many cases the parking capacity or logistics of entry is not addressed in the Slovak Republic when constructing new logistics and industrial parks, it was necessary to propose a general procedure or formula to calculate the number of parking spaces. The proposed procedure was verified at the production company of KIA Motors Slovakia. Based on the surveys carried out, it was possible to obtain input data for calculation of number of parking spaces for freight vehicles of N3 category.

The proposed calculation formula can be also used to calculate necessary number of parking spaces for other companies. However, it is necessary to carry out further surveys for a given logistics or industrial park in order to refine the formula in terms of the accuracy of coefficients for calculation of number of parking spaces for vehicles, the drivers of which draw daily or weekly rest periods. The authors suggest to include their proposal for calculation of parking spaces for freight vehicles into Slovak technical standards as it already exists in case of parking lots for passenger cars under the construction proceedings according to STN 73 6110/Z2 Design of urban roads. In comparison with Czech technical standard ČSN 736056 Parking areas for road vehicles from 2011, the issue related to parking lots for freight vehicles is elaborated more in detail, however, the calculation methodology misses.

This paper is supported by the research project "From horse-drawn railway to intermodal transport" within Visegrad Fund.

\section{References}

1. Dalnice, parkoviste, kamiony, Available online: http://www.denik.cz/ekonomika/dalnice_parkoviste_kamiony2007.html (2007)

2. J. Čársky, Parkováni vozidel nákladni dopravy, Available online: http://www.silnicezeleznice.cz/clanek/parkovani-vozidel-tezke-nakladni-dopravy/ (2010)

3. M. Poliak, J. Gnap, Práca vodičov nákladných automobilov a autobusov a používanie tachografov (University of Zilina, Slovakia, 2015)

4. J. Gnap et al., Logistika vstupu č. 2 a č. 3 MONDI SCP, a.s. (University of Zilina, Department of Road and Urban Transport, Žilina, Slovakia, 2008)

5. Kia-reports, Available online: http://www.kia.sk/sk/o-nas/vyrocne-spravy (2016)

6. Regulation (EC) No. 561/2006

7. J. Gnap, Modelovanie dopravného a prepravného procesu v cestnej nákladnej doprave (University of Zilina, EDIS, Slovakia, 2013)

8. J. Černý, P. Kluvánek, Základy matematickej teórie dopravy, 278 p. (VEDA, Bratislava, Slovakia, 1991)

9. D. Malindžák et al., Aplikácia modelovania a simulácie v logistike podniku, (Technical University of Kosice, Slovakia, 2009)

10. J. Lizbetin, O. Stopka, ICTTE - Proceedings of the third international conference on traffic and transport engineering (Belgrade, Serbia, 2016)

11. M. Rieser, Adding Transit to an Agent-Based Transportation Simulation, (Technische Universität Berlin, Germany, 2010)

12. M. Al-Azzawi, Freight and Logistics Transport Modelling and Planning (LAP LAMBERT Academic Publishing, Saarbrücken, Germany, 2012) 